Article

\title{
Toxic Oligomeric Alpha-Synuclein Variants Present in Human Parkinson's Disease Brains Are Differentially Generated in Mammalian Cell Models
}

\author{
Wei Xin ${ }^{1}$, Sharareh Emadi ${ }^{1}$, Stephanie Williams ${ }^{1}$, Qiang Liu ${ }^{2}$, Philip Schulz ${ }^{1}$, Ping He ${ }^{1}$, \\ Now Bahar Alam ${ }^{1}$, Jie Wu ${ }^{2}$ and Michael R. Sierks ${ }^{1, *}$ \\ 1 Chemical Engineering, Arizona State University, Tempe, AZ 85287-6106, USA; \\ E-Mails: wie.xin@asu.edu (W.X.); sharareh.emadi@asu.edu (S.E.); swilli4@asu.edu (S.W.); \\ Philip.Schulz@asu.edu (P.S.); pinghe2@asu.edu (P.H.); nalam1@asu.edu (N.B.A.) \\ 2 Division of Neurology, Barrow Neurological Institute, Phoenix, AZ 85013, USA; \\ E-Mails: qiang.liu@asu.edu (Q.L.); jie.wu@DignityHealth.org (J.W.) \\ * Author to whom correspondence should be addressed; E-Mail: sierks@asu.edu; \\ Tel.: +1-480-965-2828; Fax: +1-480-727-9321.
}

Academic Editor: Stephan N. Witt

Received: 15 January 2015 / Accepted: 26 June 2015 / Published: 22 July 2015

\begin{abstract}
Misfolding and aggregation of $\alpha$-synuclein into toxic soluble oligomeric $\alpha$-synuclein aggregates has been strongly correlated with the pathogenesis of Parkinson's disease (PD). Here, we show that two different morphologically distinct oligomeric $\alpha$-synuclein aggregates are present in human post-mortem PD brain tissue and are responsible for the bulk of $\alpha$-synuclein induced toxicity in brain homogenates from PD samples. Two antibody fragments that selectively bind the different oligomeric $\alpha$-synuclein variants block this $\alpha$-synuclein induced toxicity and are useful tools to probe how various cell models replicate the $\alpha$-synuclein aggregation pattern of human PD brain. Using these reagents, we show that mammalian cell type strongly influences $\alpha$-synuclein aggregation, where neuronal cells best replicate the PD brain $\alpha$-synuclein aggregation profile. Overexpression of $\alpha$-synuclein in the different cell lines increased protein aggregation but did not alter the morphology of the oligomeric aggregates generated. Differentiation of the neuronal cells into a cholinergic-like or dopaminergic-like phenotype increased the levels of oligomeric $\alpha$-synuclein where the aggregates were localized in cell neurites and cell bodies.
\end{abstract}


Keywords: Parkinson's disease; $\alpha$-synuclein; aggregation; scFv antibody; neuroblastoma cells (SH-SY5Y)

\section{Introduction}

Parkinson's disease (PD) is a progressive neurodegenerative disorder that affects approximately $1 \%$ of people aged 65 and older [1]. Clinically, PD is characterized by severe motor dysfunction including muscular rigidity, uncontrollable resting tremor and bradykinesia [1,2]. Pathologically, PD is characterized by the selective and progressive loss of dopaminergic neurons in the substantia nigra pars compacta, resulting in reduction of dopamine in its striatal projections and other brainstem regions. PD is also characterized by the presence of cytoplasmic and neuritic fibrillar inclusions known as Lewy bodies (LB) and Lewy neurites in the surviving dopaminergic neurons and other affected areas of the central nervous system [3,4]. The presence of LBs is related with either neuronal dysfunction or neuronal death depending on the brain region and the stage of disease $[5,6]$. The protein $\alpha$-synuclein was shown to be a primary constituent of LBs in sporadic PD and other neurodegenerative diseases [7-11]. While most cases of PD are sporadic, both genetic mutations in the $\alpha$-synuclein gene (A53T, A30P, and E46K) and gene duplication resulting in overexpression of $\alpha$-synuclein have been associated with familial forms of PD $[2,12,13]$. A small natively unstructured protein $(14 \mathrm{kDa}), \alpha$-synuclein is expressed mainly in brain tissues and localized in the presynaptic terminals of neurons [14]. $\alpha$-Synuclein can misfold and assemble in vitro into a variety of $\beta$-sheet based aggregates including small soluble oligomeric, larger soluble protofibrillar, and fibrillar species. Environmental factors can influence $\alpha$-synuclein folding as metal ions including aluminum, copper, iron, and calcium, heparin, catecholamines such as dopamine, and pesticides such as rotenone have all been observed to facilitate stabilization of $\alpha$-synuclein into its $\beta$-sheet conformation [15-19]. While several morphologies of $\alpha$-synuclein can be generated in vitro, increasing evidence suggest that different soluble oligomeric species rather than mature fibril forms are responsible for neuronal dysfunction and toxicity in PD disease [20-24]. Aggregated forms of $\alpha$-synuclein have been shown to induce toxicity in dopaminergic neurons in vivo [25], and different toxic mechanisms have been associated with various different aggregated morphologies [26]. Elevated extracellular levels of oligomeric $\alpha$-synuclein have also been detected in blood plasma and cerebrospinal fluid in PD patients, implicating these aggregates as important in the etiology of PD [27-31].

While $\alpha$-synuclein is considered an important target for studying PD, its role in the progression of PD pathogenesis is still largely unknown because of the complex array of different $\alpha$-synuclein morphologies that exist and the lack of suitably selective tools and reagents to probe the roles of these different species in PD models and tissues. In our lab, we have generated reagents that recognize several distinct morphologies of $\alpha$-synuclein including two different oligomeric forms: the D5 antibody fragment binds to an in vitro generated SDS-stable dimeric and tetrameric $\alpha$-synuclein, and the $10 \mathrm{H}$ antibody fragment binds to an in vitro generated SDS-stable trimeric and hexameric $\alpha$-synuclein [20,21,32]. Here, we utilized the two different $\alpha$-synuclein oligomer specific antibody fragments (D5 and 10H) [20,21] to identify the predominant cytotoxic species present in brain homogenates from post-mortem human 
PD brain tissue. The PD brain homogenates were shown to be substantially more cytotoxic to SH-SY5Y cells compared to brain homogenates from age matched cognitively normal brain homogenates. The increased cytotoxicity could be largely blocked in a concentration dependent manner by addition of D5 and/or $10 \mathrm{H}$, indicating that most of the increased neuronal toxicity in human PD brain tissue samples compared to age matched control samples is attributable to the presence of specific oligomeric $\alpha$-synuclein species. We then studied how well mammalian cell lines replicate the presence of these toxic $\alpha$-synuclein species. We probed for the presence of both the $\mathrm{D} 5$ and $10 \mathrm{H}$ reactive toxic $\alpha$-synuclein aggregates in different mammalian cell lines expressing endogenous levels of $\alpha$-synuclein including non-differentiated and differentiated human neuroblastoma cells (SH-SY5Y), Chinese hamster ovary (CHO) cells and human embryonic kidney (HEK) cells. We also utilized HEK, CHO and SH-SY5Y cells that overexpress $\alpha$-synuclein to determine whether overexpression of $\alpha$-synuclein can alter the protein aggregation pathway. Undifferentiated SH-SY5Y cells have been widely used as a PD cell model; however, this cell line can be differentiated to cholinergic-, adrenergic-, or dopaminergic- phenotypes by altering growth conditions. Sequential exposure of SH-SY5Y cells to retinoic acid and brain derived neurotrophic factor (BDNF) in serum-free medium yields homogeneous populations of fully differentiated cholinergic-like and dopaminergic-like neuronal cells which are very comparable to primary neurons [33-36]. Here, we show that the choice of cell model and differentiation state can quite dramatically impact the $\alpha$-synuclein aggregation process.

\section{Results and Discussion}

The protein $\alpha$-synuclein has been strongly linked with PD and other related neurodegenerative disorders [7,10,37]. The $\alpha$-synuclein protein occurs in vivo in various forms and morphologies [8,38,39], and can interact with membranes [40-42], other proteins such as tau, p25alpha, tubulin, and transcription factor ELK-1 [43-45], metal ions including aluminum, copper, calcium, and iron [19], and catecholamines such as dopamine $[15,46]$. The various interactions can facilitate formation of different aggregate $\alpha$-synuclein species. While ample evidence indicates that $\alpha$-synuclein plays an important role in the pathogenesis of PD, the impact of the various conformations of $\alpha$-synuclein in the progression of PD is much debated and poorly understood. Elevated levels of oligomeric $\alpha$-synuclein in CSF and plasma from PD patients and in the brain samples of Lewy bodies from dementia patients has been demonstrated $[28,47]$. We developed antibody fragments that selectively recognize two different toxic oligomeric $\alpha$-synuclein species, D5 recognizing an in vitro generated SDS stable dimeric species [20], and $10 \mathrm{H}$ recognizing an in vitro generated SDS trimeric species [21]. We showed that both of the oligomeric aggregate species occurred in human post-mortem PD brain tissue [20,21] and CSF samples [30]. Here, we show that the D5 and $10 \mathrm{H}$ reactive oligomeric $\alpha$-synuclein variants account for the bulk of cytotoxicity induced by human PD brain tissue homogenates.

We utilized the human neuroblastoma cell line, SH-SY5Y, to determine cytotoxicity of homogenized post-mortem human PD and control brain tissue samples in vitro [48]. We first quantified the levels of both D5 and $10 \mathrm{H}$ reactive $\alpha$-synuclein aggregates in the human PD and control patient brain homogenates using capture ELISA [49] (Figure 1). The PD brain homogenates showed significantly higher levels of oligomeric $\alpha$-synuclein than the age-matched control samples, though the distribution of D5 and 10H oligomeric species varied among PD patients. We separated the 10 different PD brain 
homogenate samples into two different PD mixes; PD-1 containing five tissue samples that have similar levels of both D5 and $10 \mathrm{H}$ reactive oligomeric $\alpha$-synuclein (Figure 1A), and PD-2 containing tissue samples that have substantially higher levels of $10 \mathrm{H}$ reactive oligomeric $\alpha$-synuclein compared to D5 reactive $\alpha$-synuclein levels (Figure 1B). Total $\alpha$-synuclein levels in the control, PD-1 and PD-2 samples were all similar (Figure 1C). The different binding specificities of the D5, $10 \mathrm{H}$ and D10 scFvs toward different aggregate morphologies of $\alpha$-synuclein are shown in Figure 1D.

A

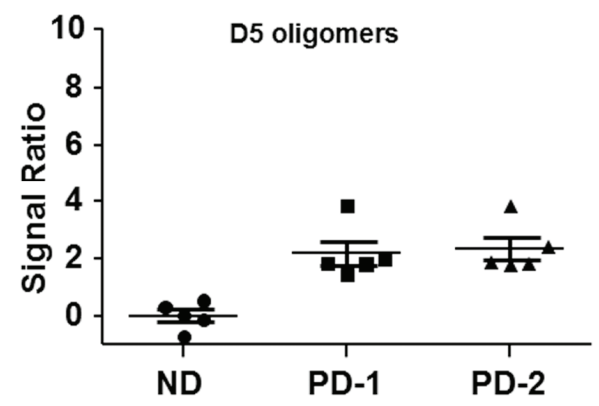

C

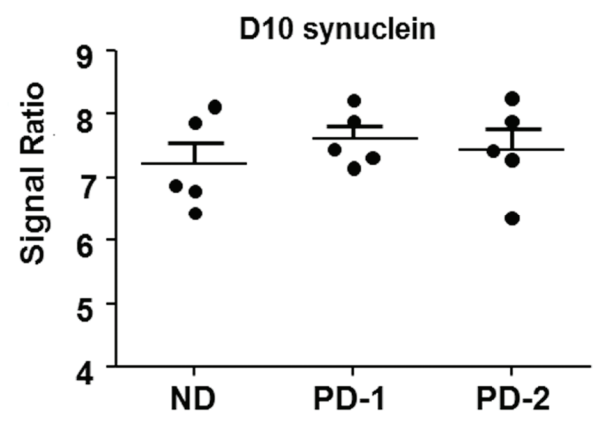

B

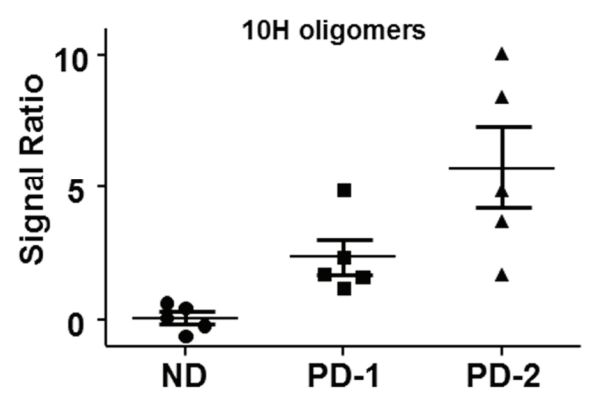

D

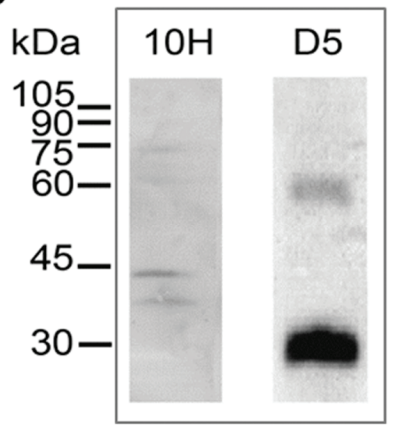

$15-$

E

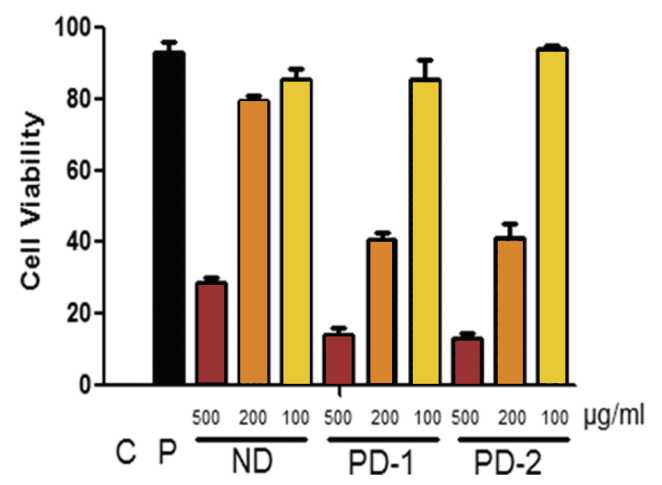

Figure 1. D5 and $10 \mathrm{H}$ reactive $\alpha$-synuclein oligomers in human patient brain samples and their cytotoxicity in SH-SY5Y cell model. (A)-(C) Relative amounts of D5 and 10H reactive $\alpha$-synuclein oligomers and D10 $\alpha$-synuclein (reacting with total $\alpha$-synuclein) present in different human PD and control brain homogenates; (D) Western blot of D5, $10 \mathrm{H}$ and D10 scFv binding specificity with $\alpha$-synuclein aggregates (adapted from [20,21]); (E) Toxicity of homogenized brain tissue from PD-1, PD-2 and ND control brain pools towards SH-SY5Y cells. C is a SHSY5Y cell-free control corresponding to $0 \%$ cell viability limit. P is a healthy SHSY5Y cell control corresponding to $100 \%$ cell viability limit. 
After identifying the concentration of the different oligomeric $\alpha$-synuclein species in the brain homogenate samples, we then determined the toxicity of the samples when incubated with SH-SY5Y cells. We varied the concentration of brain tissue homogenate $(1000,500,200,100,50,20$ and $0 \mu \mathrm{g} / \mathrm{mL}$ total protein) incubated with the cells to determine toxicity of the PD brain homogenates relative to control brain homogenates (Figure 1E). At the highest concentration $(1000 \mu \mathrm{g} / \mathrm{mL})$ both ND and PD samples were overly toxic to the SH-SY5Y cells, and, at the lower concentrations (50, 20 and $0 \mu \mathrm{g} / \mathrm{mL}$ ), there was minimal toxicity under the assay conditions employed. However, at total brain protein concentrations of 500, 200 and $100 \mu \mathrm{g} / \mathrm{mL}$, there was a significant difference in toxicity observed between the PD and control samples (Figure 1E). The differences in toxicity between both the PD-1 and PD-2 and control samples were most pronounced at a protein concentration of $200 \mu \mathrm{g} / \mathrm{mL}$, so this protein concentration was utilized for further toxicity studies.

We next determined if the increased cytotoxicity of the PD brain homogenates was attributable to oligomeric $\alpha$-synuclein aggregates. When the brain homogenates were added to the SH-SY5Y cells, we also added different concentrations of either D5 or $10 \mathrm{H}$ to selectively target and block different $\alpha$-synuclein aggregates. For the PD-1 brain homogenate sample which contained approximately equivalent amounts of both D5 and $10 \mathrm{H}$ reactive oligomeric $\alpha$-synuclein, cell viability was increased from $40.7 \%$ without added $\mathrm{scFv}$ to $70.1 \%$ at the highest D5 concentration (Figure $2 \mathrm{~A}$ ) and $62.3 \%$ at the highest $10 \mathrm{H}$ concentration (Figure $2 \mathrm{~B}$ ). When both D5 and $10 \mathrm{H} \mathrm{scFvs} \mathrm{were} \mathrm{incubated} \mathrm{together} \mathrm{with} \mathrm{the} \mathrm{brain}$ tissue homogenates and cells, the cell viability increased to $91.1 \%$ (Figure 2C) neutralizing most of the additional toxicity in the PD-1 sample mix relative to the control brain sample. The PD-2 brain homogenate sample mixture contains brain tissue homogenates that contain higher levels of $10 \mathrm{H}$ compared to D5 reactive oligomeric $\alpha$-synuclein aggregates. When cells were incubated with the PD-2 brain tissue mixture and with $10 \mathrm{H} \mathrm{scFv}$, cell viability was increased from $40.7 \%$ without added scFv to nearly $80 \%$ (Figure 2E), but only to around 60\% when co-incubated with D5 (Figure 2D). When both D5 and $10 \mathrm{H}$ scFvs were incubated with the PD-2 brain tissue sample the cell viability increased slightly more compared to treatment with $10 \mathrm{H}$ alone (87.2\%) (Figure $2 \mathrm{~F}$ ).

With both the PD-1 and PD-2 brain mixture samples, addition of both D5 and 10H restored cell viability to around $90 \%$ of that observed when cells were incubated with PBS buffer. Therefore, D5 and $10 \mathrm{H}$ reactive $\alpha$-synuclein aggregates are two of the primary pathological toxic $\alpha$-synuclein species that are present in post-mortem human PD brain tissue. Cell models used to replicate the $\alpha$-synuclein aggregation process should also be able to replicate the presence of these toxic oligomeric species. To identify which cell models best replicate the $\alpha$-synuclein pathology observed in the human PD brain, we probed several different mammalian cell lines with D5 and $10 \mathrm{H}$ scFvs to determine how well they recreated the $\alpha$-synuclein aggregation profile found in human brain tissue. We studied how both different cell genotypes (CHO, HEK293 and SH-SY5Y) as well as cell phenotypes (undifferentiated, cholinergic-like and dopaminergic-like SH-SY5Y cells) affect $\alpha$-synuclein generation in situ. The choice of cell line rather dramatically influences which $\alpha$-synuclein aggregates are generated. CHO cells did not react with either D5 (Figure 3A-I) or 10H (Figure 3A-IV), while HEK cells reacted strongly with D5, but only very weakly with $10 \mathrm{H}$ (Figure 3A-II,-V), and SH-SY5Y cells reacted strongly with both $10 \mathrm{H}$ (Figure 3A-III) and D5 (Figure 3A-VI). 
A

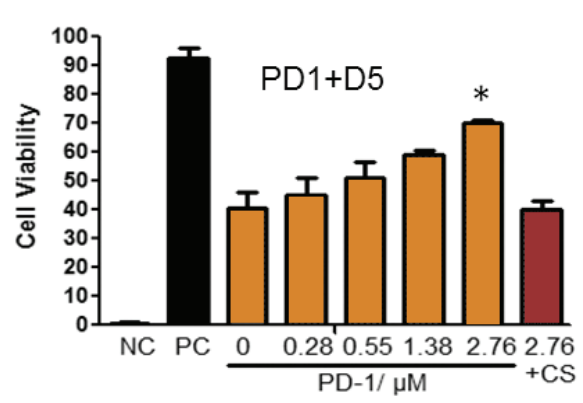

D

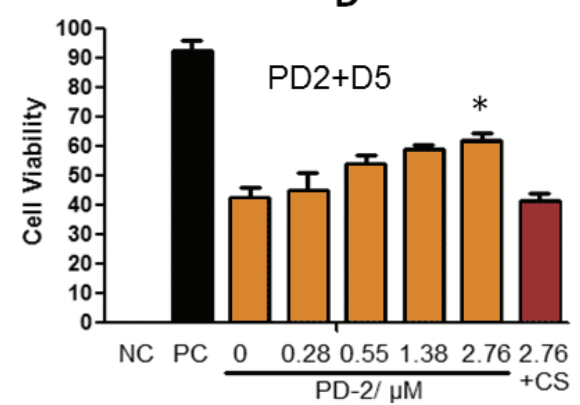

B

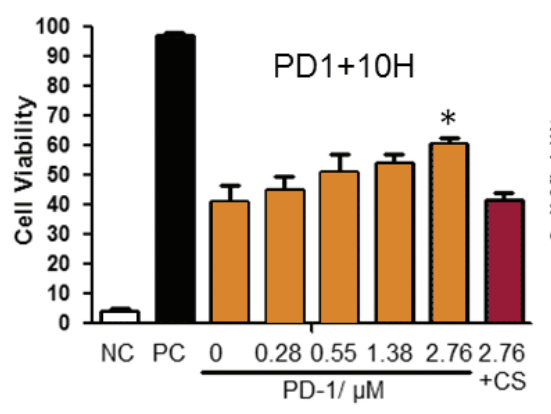

E

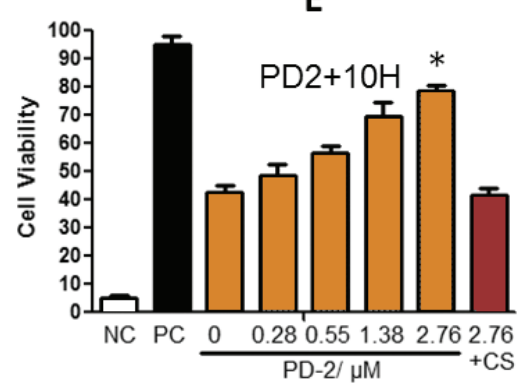

C

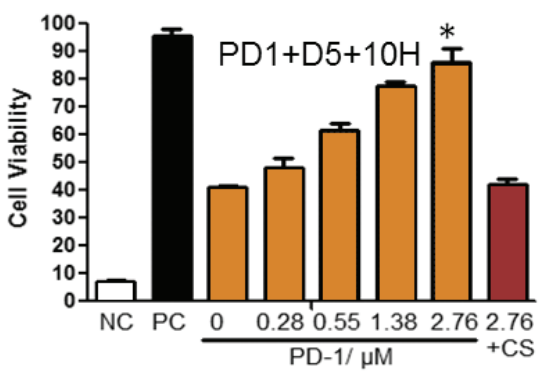

$\mathbf{F}$

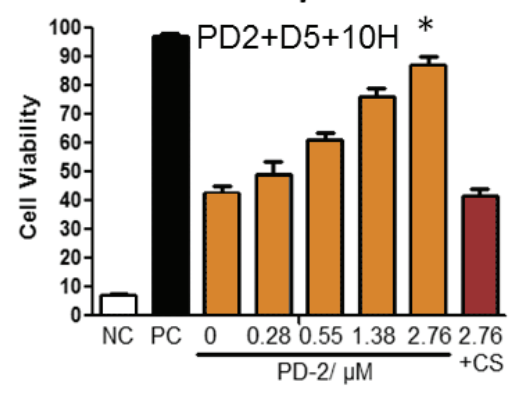

Figure 2. D5 and/or $10 \mathrm{H} \mathrm{scFv}$ neutralize toxicity of different human PD brain tissue samples (PD-1 and PD-2 mix) toward SH-SY5Y cells. SH-SY5Y cells were treated with PD patient brain homogenized supernatants $(200 \mu \mathrm{g} / \mathrm{mL})$ with or without different concentrations of D5 or/and $10 \mathrm{H}$ scFvs $(0.28,0.55,1.38$ and $2.76 \mu \mathrm{M})$ for $24 \mathrm{~h}$ with medium. NC is the no cell baseline value. PC (Positive control, healthy SH-SY5Y cells treated with control brain tissue, $200 \mu \mathrm{g} / \mathrm{mL}$ ). $2.76+\mathrm{CS}$ is the antibody control group treated with PD patient brain homogenized supernatants $(200 \mu \mathrm{g} / \mathrm{mL})$ and $2.76 \mu \mathrm{M}$ of a control scFv. Cell viability was determined by the XTT assay. Cell viability is expressed by the mean of three measurements \pm 1 standard deviation. Statistical significance was determined between different groups. $*$ is $p<0.05$.

CHO

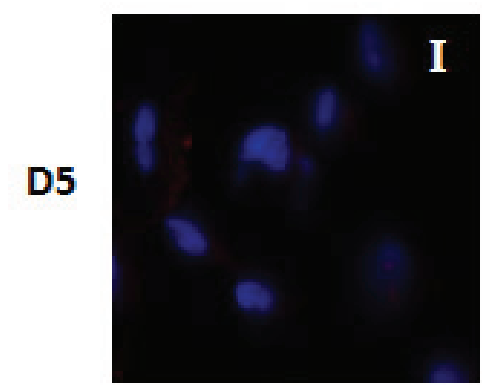

$10 \mathrm{H}$
HEK
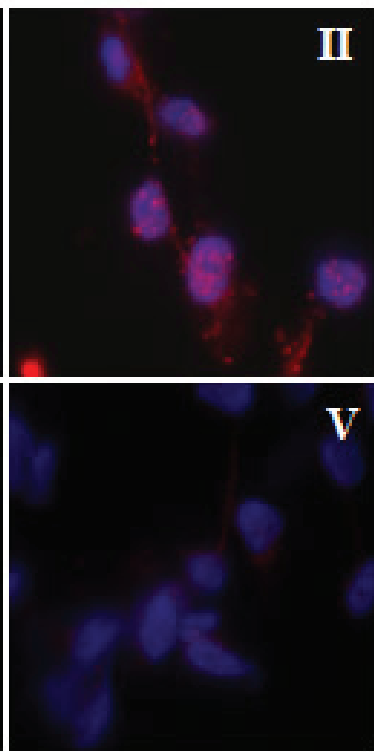

(A)
SH-SY5Y

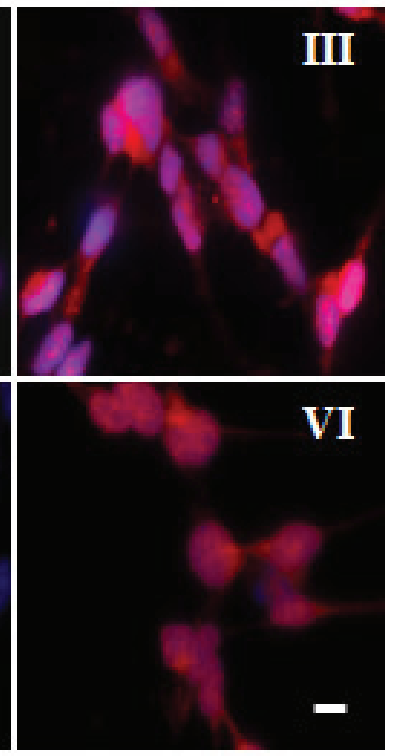

VI 
Figure 3. Cont.

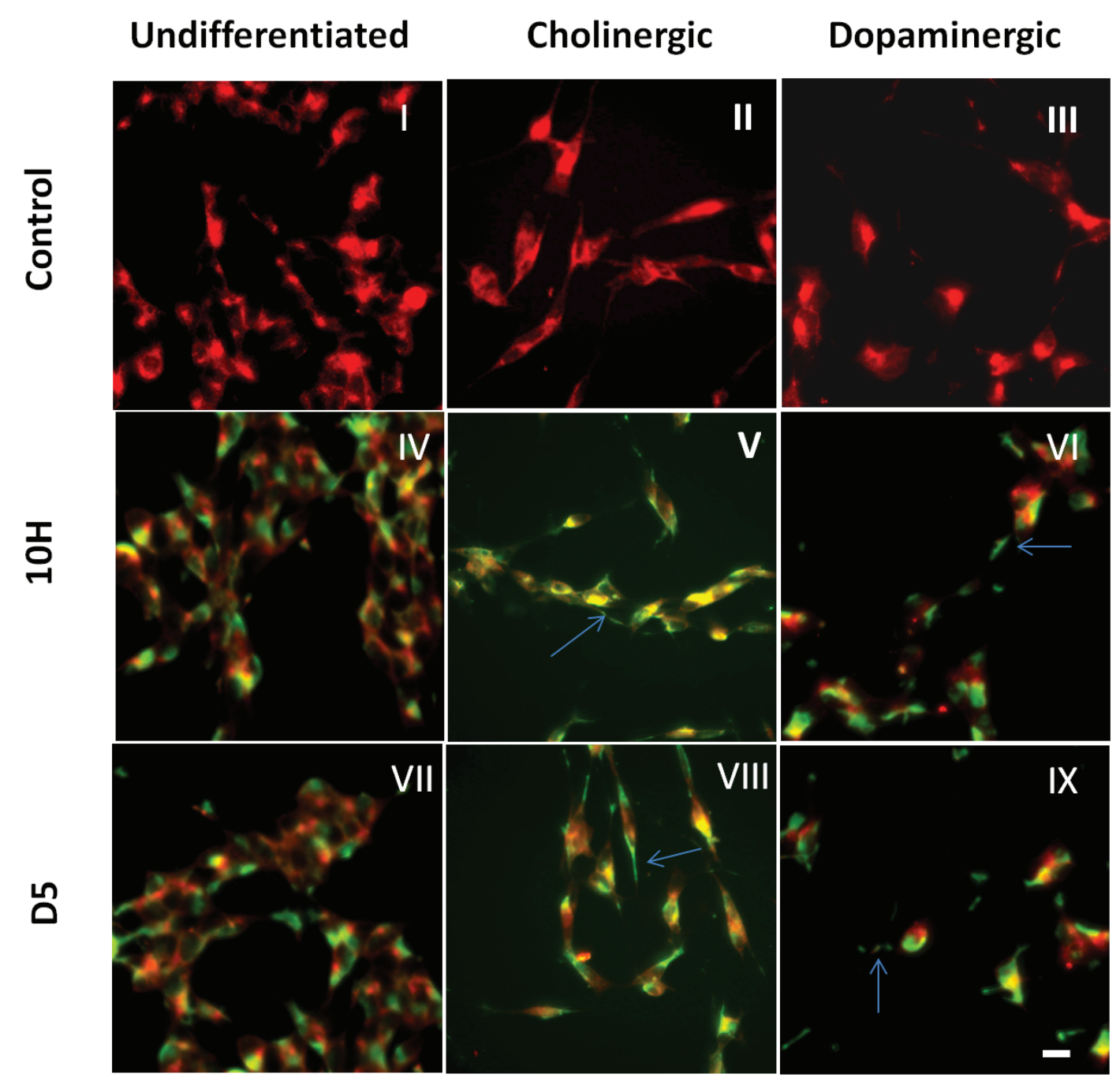

(B)

Figure 3. Localization of D5 and $10 \mathrm{H}$ reactive $\alpha$-synuclein aggregates in different cell lines. (A) Localization of $\alpha$-synuclein aggregates in CHO, HEK and SH-SY5Y cells. Cells were fixed with formaldehyde and probed without or with $0.2 \mathrm{mg} / \mathrm{mL}$ of D5 (red), $10 \mathrm{H}$ (red) and DAPI (blue); (B) Staining of D5 and $10 \mathrm{H}$ reactive oligomeric $\alpha$-synuclein morphologies in undifferentiated (I, IV, VII) and differentiated cholinergic-like cell (II, V, VIII) and dopaminergic-like SH-SY5Y cells (III, VI, IX); The undifferentiated cells were treated with anti-synaptophysin (red) (I, IV, VII), the cholinergic-like cells with anti-ChAT (red) (II, V, VIII), and the dopaminergic-like cells with anti-TH, (red) (III, VI, IX). Cells were fixed in $4 \%$ formaldehyde and probed without (I, II, III) or with $10 \mathrm{H}$ (IV, V, VI) or with D5 (VII, VIII, IX) (green) scFv antibody fragments. Arrows indicate staining in neurites. The scale bar equal to $50 \mu \mathrm{m}$.

Because dopaminergic cells are preferentially targeted in PD, we tested whether different neuronal cell phenotypes can alter $\alpha$-synuclein aggregation. We generated three different neuronal cell phenotypes (non-differentiated, cholinergic-like, and dopaminergic-like) from SH-SY5Y human neuroblastoma cell line by sequential exposure of cells to RA and BDNF using previously described protocols [33-35]. 
These protocols provide homogeneous populations of fully neuronal, differentiated cells that are very comparable to primary neurons and exhibit characteristics of cholinergic and dopaminergic neurons, including expression of choline acetyltransferase (ChAT), vesicular monoamine transporter (VMAT), and tyrosine hydroxylase (TH) [33-35,50-53]. We confirmed cell phenotype by verifying expression of neuronal differentiation markers. Cholinergic-like SH-SY5Y cells treated with RA for five days showed high expression of ChAT (Figure 3B-II), while dopaminergic-like cells treated sequentially with RA and BDNF showed extensive expression of TH (Figure 3B-III). After verifying that we had cholinergic-like and dopaminergic-like neuronal cells, we then probed the different cell types for the presence of oligomeric $\alpha$-synuclein with $\mathrm{D} 5$ and $10 \mathrm{H}$ scFvs. The undifferentiated, cholinergic-like and dopaminergic-like SH-SY5Y cells all showed similar labeling with 10H (Figure 3B-IV, -V and -VI), where the $10 \mathrm{H}$ reactive $\alpha$-synuclein aggregates were preferentially localized in the cell body in all cases with only slight staining of neurites. In contrast, the undifferentiated SH-SY5Y cells showed D5 reactive oligomeric $\alpha$-synuclein aggregates present in the cytoplasm similar to $10 \mathrm{H} \alpha$-synuclein aggregates (Figure 3B-VII), while the cholinergic-like and dopaminergic-like cells also showed significant D5 reactive oligomeric $\alpha$-synuclein aggregates in the cell neurites and cell body (Figure 3B-VIII,-IX). These results indicate that the D5 reactive $\alpha$-synuclein species are produced by all three neuronal phenotypes in the cell body, however cholinergic-like and dopaminergic-like cells also produce D5 reactive $\alpha$-synuclein aggregates in the cell neurites. The $10 \mathrm{H}$ reactive oligomeric $\alpha$-synuclein species occurs predominantly in the cell body for all three neuronal phenotypes, though they are also present in cell neurites in both cholinergic-like and dopaminergic-like cells.

Therefore, a variety of different oligomeric $\alpha$-synuclein aggregates are produced by different cell types even when $\alpha$-synuclein is expressed at normal levels. Our results indicate that the type and location of the $\alpha$-synuclein aggregates generated depend on both cell genotype and phenotype, where dopaminergic and cholinergic neurons preferentially generate a toxic oligomeric $\alpha$-synuclein species in neurites compared to other cell types. We postulate that in healthy cells these oligomeric aggregates are cleared through normal cellular mechanisms including proteasomal clearance and autophagy [54]; however, when these clearance processes begin to fail, toxic oligomeric $\alpha$-synuclein species begin to accumulate and may spread to healthy cells through an exosomal mediated mechanism $[26,55,56]$.

Since overexpression of $\alpha$-synuclein has been extensively used in cell and animal models of PD, we also studied how overexpression of $\alpha$-synuclein affects the aggregation state of $\alpha$-synuclein. We induced $\alpha$-synuclein overexpression in CHO, HEK, and SH-SY5Y cells by transfection with the WTsynEGFP gene so excess expression of $\alpha$-synuclein could be readily verified by fluorescence. We then investigated whether there was a change in oligomeric $\alpha$-synuclein aggregation induced by overexpression. Overexpression of $\alpha$-synuclein in CHO cells still did not result in the presence of D5 (Figure 4A) or $10 \mathrm{H}$ (Figure 4D) reactive $\alpha$-synuclein aggregates similar to what we observed when the cells expressed endogenous levels of $\alpha$-synuclein (Figure 3A-I,-IV). Similarly with HEK cells, overexpression of $\alpha$-synuclein led to the presence of both D5 (Figure 4B) and 10H (Figure 4E) reactive $\alpha$-synuclein aggregates with much higher presence of D5 reactive aggregates than $10 \mathrm{H}$ again similar to results observed with endogenous expression (Figure 3A-II,-V). Finally, with undifferentiated SH-SY5Y cells, $10 \mathrm{H}$ and D5 reactive $\alpha$-synuclein aggregates were observed (Figure 4C,F), again similar to the results observed with endogenous levels of $\alpha$-synuclein expression (Figure $3 \mathrm{~A}-\mathrm{III},-\mathrm{VI}$ ). 


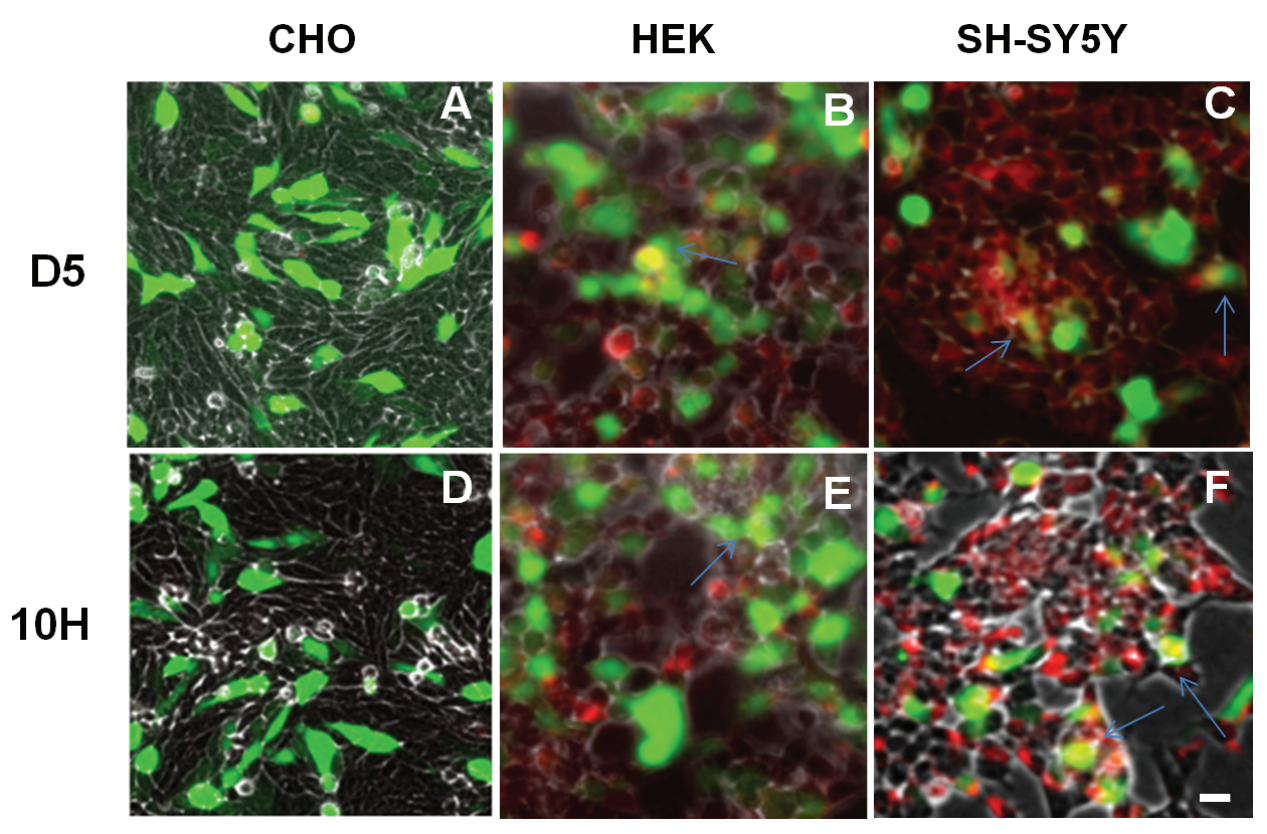

Figure 4. Localization of D5 and $10 \mathrm{H}$ reactive $\alpha$-synuclein aggregates in $\mathrm{CHO}$, HEK and SH-SY5Y cells overexpressing $\alpha$-synuclein. Cells were seeded in 6-well plates with a density of $10^{5}$ cells/well and treated with 2:1 transfected reagent and wt-synuclein-EGFP (green). After $72 \mathrm{~h}$, the cells were fixed with formaldehyde and probed without or with D5 or $10 \mathrm{H}$ $\mathrm{scFv}$ antibody fragments (red). Arrows indicate co-localization. The scale bar equal to $50 \mu \mathrm{m}$.

We quantified the levels of total $\alpha$-synuclein and the D5, $10 \mathrm{H}$ reactive oligomeric $\alpha$-synuclein in the different cell lines expressing both endogenous and overexpressed levels of $\alpha$-synuclein by ELISA (Figure 5). Overexpression of $\alpha$-synuclein in CHO cells did not result in a significant increase in D5 or $10 \mathrm{H}$ reactive $\alpha$-synuclein aggregates in the supernatant or cell lysate although the total $\alpha$-synuclein levels (D10) were substantially higher in supernatant and lysate. Overexpression of $\alpha$-synuclein in HEK cells only very modestly increased levels of D5 and $10 \mathrm{H}$ reactive oligomeric $\alpha$-synuclein in both supernatant and lysate cells $(p<0.05$ ) (Figure 5). However, overexpression of $\alpha$-synuclein in undifferentiated SH-SH5Y cells significantly increased levels of D5 reactive oligomeric $\alpha$-synuclein in both supernatant and cell lysates, while $10 \mathrm{H}$ levels reactive $\alpha$-synuclein levels did not increase substantially with $\alpha$-synuclein overexpression (Figure 5). Therefore, overexpression of $\alpha$-synuclein does not induce formation of toxic oligomeric $\alpha$-synuclein variants in cell lines that do not naturally produce them; however, the levels of different $\alpha$-synuclein species generated may vary with expression level. These results indicate that in PD models, choice of cell type affects the $\alpha$-synuclein aggregation process and cytotoxicity much more than expression levels.

In summary, oligomeric $\alpha$-synuclein aggregates represent the primary cytotoxic $\alpha$-synuclein species present in post-mortem human PD brain tissue and this toxicity can be largely eliminated by targeting two different morphological species of $\alpha$-synuclein aggregate using the D5 and $10 \mathrm{H}$ scFvs. We further show that when trying to replicate this toxic $\alpha$-synuclein pathology in PD models, both cell genotype and phenotype strongly influence the aggregation state of $\alpha$-synuclein, though expression levels do not. Differentiation of SH-SY5Y cells into cholinergic and dopaminergic phenotypes gave distinct $\alpha$-synuclein aggregation patterns that were similar to those observed with rat primary neurons, suggesting that differentiated neurons may be a reasonable cell model to study $\alpha$-synuclein toxicity in PD. 

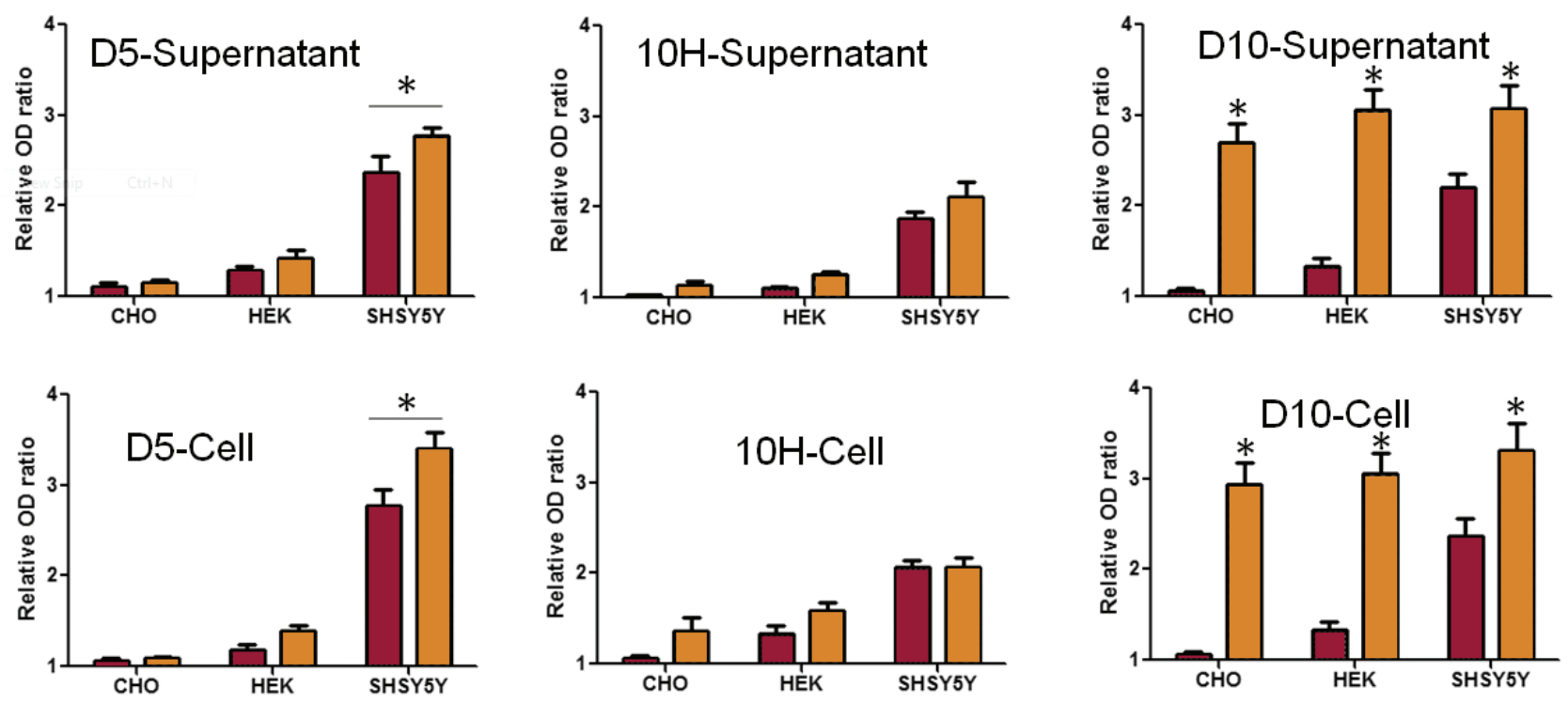

Untransfected $\square$ WTsynEGFP

Figure 5. The levels of total $\alpha$-synuclein (D10) and D5 and $10 \mathrm{H}$ reactive oligomeric $\alpha$-synuclein aggregates in cell supernatant and lysate with endogenous and overexpressed levels of $\alpha$-synuclein. Levels of the different $\alpha$-synuclein species were determined by capture ELISA (D5 and 10H) or by indirect ELISA (D10) [49]. Cells $\left(10^{5} / \mathrm{mL}\right)$ were seeded in a six well plate and transfected with or without wt-synuclein-EGFP. $\alpha$-Synuclein levels are expressed as the mean value of three measurements \pm standard deviation. Statistical significance was determined at transfected cells $v s$. normal cells. $*$ is $p<0.05$.

\section{Experimental Section}

\subsection{Materials}

Cell Culture

HEK293 Cells. Human embryonic kidney (HEK293) cells were cultured in Dulbecco's Modified Eagle Medium (DMEM), from Invitrogen, supplemented with 10\% fetal bovine serum (FBS, Sigma, St Louis, MO, USA), 1\% penicillin/streptomycin and 2\% L-glutamine (Life Technologies, New York, NY, USA) at $37{ }^{\circ} \mathrm{C}$, in a $5 \% \mathrm{CO}_{2}$ atmosphere. HEK293 cells were generous gifts from Nick Webster (Wadsworth Center, Albany, NY, USA).

CHO Cells. Chinese hamster ovary cells $(\mathrm{CHO})$ cells were cultured in the same medium as above, supplemented with $10 \%$ fetal bovine serum, 1\% penicillin/streptomycin and 1\% L-glutamine (Life Technologies) and grown at $37{ }^{\circ} \mathrm{C}$, in a $5 \% \mathrm{CO}_{2}$ atmosphere. $\mathrm{CHO}$ cells [57] were generous gifts from Dennis Selkoe (Harvard Medical School).

SH-SY5Y Cells. SH-SY5Y human neuroblastoma cell line cells were maintained in culture flasks in medium containing $(v / v)$ minimal essential medium (MEM), $(v / v)$ Ham's modification of F-12, $10 \%$ fetal bovine serum (FBS, Sigma), 1\% non-essential amino acid, and 1\% antibiotic-antimycotic (Life Technologies) and grown in a $5 \% \mathrm{CO}_{2}$ atmosphere at $37^{\circ} \mathrm{C}$. The $\mathrm{SH}-\mathrm{SY} 5 \mathrm{Y}$ cell line was purchased from ATCC (Vienna, VA, USA), minimal essential medium (MEM) and Ham's modification F-12 were obtained 
from Irvine Scientific (Santa Ana, CA, USA). Non-essential amino acids and antibiotic-antimycotic 100x were obtained from Invitrogen (Carlsbad, CA, USA). All chemicals were obtained from Sigma-Aldrich (St. Louis, MO, USA) unless otherwise indicated.

Differentiated SH-SY5Y Cells. SH-SY5Y cells were harvested from flasks and plated in 6-well polystyrene plates (Corning Inc., Corning, NY, USA) coated previously with $0.5 \mathrm{mg} / \mathrm{mL}$ collagen with density of $10^{5}$ cells per well. The cells were differentiated to cholinergic-like neuronal cells by addition of $10 \mu \mathrm{M}$ retinoic acid (Sigma-Aldrich) in media with serum for 4 days at $37{ }^{\circ} \mathrm{C}$. After 4 days in the presence of RA, cells were differentiated to dopaminergic-like neuronal cells by incubating with $50 \mathrm{ng} / \mathrm{mL}$ of brain-derived neurotrophic factor (BDNF) (PeproTech, Rocky Hill, NJ, USA) in media without serum for 7 days at $37^{\circ} \mathrm{C}$ as described [33-36].

Transient Transfection of SH-SY5Y,CHO and HEK Cells. Transient transfection of cells was performed using FuGENE HD Transfection Reagent according to the manufacturer's protocol (Promega, Madison, WI, USA) with slight modification [13]. Briefly, SH-SY5Y cells ( $10^{5}$ cells/well) were seeded in $1 \mathrm{~mL}$ of growth medium in 6 well plates for 1 or 2 days before transfection $(50 \%-70 \%$ confluence). A transfection mixture consisting of wild type $\alpha$-synuclein/EGFP (WTsynEGFP) fusion protein plasmid DNA (Clontech, Palo Alto, CA, USA) and Fugene reagent (1:2 v/v) in serum-free media was pre-incubated in the dark for $15 \mathrm{~min}$. at room temperature before addition to the cells. Cell culture media was removed, and after the transfection mixture $(500 \mu \mathrm{L})$ was added to each well, the culture was incubated for $1 \mathrm{~h}$ at $37^{\circ} \mathrm{C}$, followed by addition of complete media with serum $(500 \mu \mathrm{L})$. The cultures were incubated and grown in a $5 \% \mathrm{CO}_{2}$ atmosphere at $37{ }^{\circ} \mathrm{C}$ for $72 \mathrm{~h}$. The cells were then probed with D5 or $10 \mathrm{H}$ as described above.

\subsection{Purification of D5, $10 H$ and D10 Fragments and Western Blot}

The D5 and $10 \mathrm{H}$ single chain antibody fragments ( $\mathrm{scFv}$ ) were purified using a protein A sepharose column as described previously [20,21]. Briefly, the supernatant and periplasmic fractions from a $1 \mathrm{~L}$ culture were combined, passed through a $0.2 \mu \mathrm{m}$ filter (Whatman, Clifton, NJ, USA), and then concentrated in a tangential flow filter (Millipore, Billerica, MA, USA) using a $10 \mathrm{kDa}$ filter membrane (Millipore). Concentrated samples were applied to a protein A-Sepharose column (GE healthcare, NJ, USA) which was equilibrated in PBS 1x, $\mathrm{pH} 7.4$, at $4{ }^{\circ} \mathrm{C}$. After washing the column in the same buffer, bound antibody fragments were eluted from the column with $0.2 \mathrm{M}$ glycine, $\mathrm{pH} 3$. Fractions containing antibody fragments were pooled, adjusted to neutral $\mathrm{pH}$, dialyzed into PBS and stored at $-20{ }^{\circ} \mathrm{C}$. The purity of the antibody fragments was estimated by electrophoresis on $12 \%(w / v)$ SDS-polyacrylamide gels and Western Blot (method see Emadi et al., 2007) [20,21].

\subsection{Preparation of Brain Tissue Homogenates}

Post-mortem brain tissue samples from pathologically verified age-matched non-diseased (ND) and Parkinson's disease (PD) patients were generously provided by Dr. Thomas Beach (Civin Laboratory for Neuropathology, Sun Health Research Institute, Sun City, AZ, USA) (Table 1). The middle temporal gyrus (MTG) of ten different PD samples and five age matched cognitively normal ND samples were separately homogenized in $0.1 \mathrm{M}$ Tris/Lysis buffer $(\mathrm{pH} 7.4)$ with protease inhibitor (Pierce), centrifuged and combined as PD and ND samples, respectively. The PD samples (Table 1) 
were split into two groups of five samples each based on the relative amounts of D5 and $10 \mathrm{H}$ reactive oligomeric $\alpha$-synuclein aggregates present in each sample where PD-1 group contained samples with relatively similar amounts of D5 and $10 \mathrm{H}$ reactive $\alpha$-synuclein aggregates and PD-2 group contained samples with predominantly $10 \mathrm{H}$ reactive $\alpha$-synuclein aggregates [49].

Table 1. Human Brain Samples for Parkinson's Disease PD-1, PD-2 and ND.

\begin{tabular}{ccc}
\hline Sample & Gender & Age \\
\hline & M & 85 \\
& F & 73 \\
PD-1 & M & 75 \\
& F & 74 \\
& M & 77 \\
\hline & F & 78 \\
& M & 72 \\
PD-2 & F & 91 \\
& F & 82 \\
& M & 70 \\
\hline & M & 79 \\
& M & 65 \\
ND & F & 87 \\
& M & 89 \\
& F & 83 \\
\hline
\end{tabular}

\subsection{Incubation of Human Brain Tissue Homogenates with SH-SY5Y Cells}

The toxicity of the brain tissue samples towards human neuroblastoma SH-SY5Y cells was measured using an XTT assay [48]. SH-SY5Y cell line were cultured at $37{ }^{\circ} \mathrm{C}$ in a humidified atmosphere with 5\% $\mathrm{CO}_{2}$, in a HEPES (20 mM)-buffered RPMI 1640 cell culture medium supplemented with $2 \mathrm{mM}$ L-glutamine, antibiotic/antimycotic mixture (1\%) and 10\% fetal bovine serum (FBS). Cells were treated with PD patient brain homogenized supernatants $(100 \mu \mathrm{g} / \mathrm{mL})$ with or without added D5 or $10 \mathrm{H} \mathrm{scFv}(0,0.28,0.55,1.38$ and $2.76 \mu \mathrm{M}$ of scFv in final medium) for $24 \mathrm{~h}$ with above medium. ND brain homogenized supernatants was used as control sample to show the toxicity background. Cell viability was determined by the XTT assay. The cells incubated in 96-well flat-bottom plates for the cell viability assessment were $2 \times 10^{4}$ cells/well. A freshly prepared XTT-PMS labeling mixture $(50 \mu \mathrm{L})$ was added to the cell culture and incubated for $3-4 \mathrm{~h}$. The absorbance was measured at $450 \mathrm{~nm}$ and $570 \mathrm{~nm}$ in an automated microplate reader. All sample values were normalized to a mixture containing five control patient samples (ND).

\subsection{Immunofluorescent Staining}

Cells were fixed in $4 \%$ formaldehyde in PBS at room temperature for $15 \mathrm{~min}$. Then cells were treated with $0.2 \%$ Triton 100 at room temperature for $15 \mathrm{~min}$., washed three times with PBS and blocked for $1 \mathrm{~h}$ with PBS containing 5\% goat serum. The cells were incubated overnight (ON) with $0.3 \mathrm{mg} / \mathrm{mL}$ of D5 and/or $10 \mathrm{H} \mathrm{scFv}$. The primary antibodies (mouse anti-c-Myc (Sigma), anti-Synaptophysin (Santa 
Cruz Biotechnology, Dallas, TX, USA), anti-choline acetyltransferase (Santa Cruz Biotechnology) and anti-tyrosine hydroxylase, all at a 1/100 dilution) were then applied to the cells, which were incubated for $2 \mathrm{~h}$ at room temperature. The cells were washed 3 times with PBS and incubated with 1/1000 dilution of the secondary antibodies (goat anti-mouse IgG Alexa Fluor 488 and goat anti-rabbit Alexa Fluor 594, Life Technologies) or DAPI (Sigma) for $1 \mathrm{~h}$ at room temperature. The images were taken with a fluorescent microscope (Observer D1, Zeiss).

\subsection{Capture ELISA}

High binding polystyrene microtiter plates were coated with $0.3 \mu \mathrm{g} / \mathrm{mL}$ of $\mathrm{D} 5$ or $10 \mathrm{H} \mathrm{scFv}$ in carbonate-bicarbonate, $\mathrm{pH} 9.6$ at $4{ }^{\circ} \mathrm{C}$ for overnight. Non-specific binding was blocked by incubating with $2 \%$ PBS-milk at $37{ }^{\circ} \mathrm{C}$ for $1 \mathrm{~h}$. The plates were then incubated with an aliquot of supernatant or cell lysate from untransfected and transfected SHSY5Y, CHO and HEK cells, for $2 \mathrm{~h}$ at $37^{\circ} \mathrm{C}$. After washing, an aliquot of $10^{10}$ titer units of PEG precipitated D10 phage in $100 \mu \mathrm{L}$ of $2 \%$ PBS-milk was added to each well and incubated for $90 \mathrm{~min}$ at room temperature. Bound phages were detected after 1 $\mathrm{h}$ incubation with a 1:2000 dilution of avidin- horseradish peroxidase (HRP) conjugate. A $100 \mu \mathrm{L}$ aliquot of the HRP substrate 3.3'.5.5'-tetramethylbenzidine (TMB, Sigma) was added and the reaction was stopped after $20 \mathrm{~min}$ with $2 \mathrm{M} \mathrm{H}_{2} \mathrm{SO}_{4}$. The activity was determined by subtracting $\mathrm{OD}_{650}$ from $\mathrm{OD}_{450}$ using a Wallac 1420 plate reader (Perkin Elmer, Waltham, MA, USA) and comparing absorbance between control well (without D10 phage) to the sample well (with D10 phage) where the control value was normalized to 1 .

To measure oligomer content in the brain tissue the wells were coated with $0.3 \mu \mathrm{g} / \mathrm{mL}$ of $10 \mathrm{H}$ or $\mathrm{D} 5 \mathrm{scFv}$ for $1 \mathrm{~h}$ at $37{ }^{\circ} \mathrm{C}$. The wells were then blocked for $1 \mathrm{~h}$ at $37{ }^{\circ} \mathrm{C}$ with $2 \%$ milk. Brain tissue was added at a concentration of $100 \mathrm{ug} / \mathrm{mL}$ for $1 \mathrm{~h}$ at $37^{\circ} \mathrm{C}$ followed by the detection antibody, biotinylated D10 phage, at 1/1000 dilution. Next, a 1/1000 dilution of avidin-HRP (Sigma-Aldrich) was added to wells and binding detected using the SuperSignal ELISA Femto Maximum Sensitivity Substrate kit (Thermo Scientific, Waltham, MA, USA). Signals were measured using a Wallac Victor ${ }^{2}$ microplate reader after 1 and $20 \mathrm{~min}$. Signals were compared to the PBS controls (PBS added in place of brain tissue) and then to the NDs.

\subsection{Statistical Analysis}

All the experiments were performed in triplicate unless otherwise stated. The data in the text and figures are expressed as mean \pm 1 SEM. Statistical comparisons between groups were assayed using $t$ test. One way ANOVA was used to test for significance. $P$-values less than 0.05 were considered significant. In the ELISAs, the PDs were normalized relative to the NDs. All the analyses were performed using SPSS for Windows version 13.0 (SPSS Software, IBM, Hong Kong, China).

\section{Conclusions}

In summary, oligomeric $\alpha$-synuclein aggregates represent the primary cytotoxic $\alpha$-synuclein species present in post-mortem human PD brain tissue and this toxicity can be largely eliminated by targeting two different morphological species of $\alpha$-synuclein aggregate using the D5 and $10 \mathrm{H}$ scFvs. We further 
show that, when trying to replicate this toxic $\alpha$-synuclein pathology in PD models, both cell genotype and phenotype strongly influence the aggregation state of $\alpha$-synuclein, though expression levels do not. Differentiation of SH-SY5Y cells into cholinergic and dopaminergic phenotypes gave distinct $\alpha$-synuclein aggregation patterns that were similar to those observed with rat primary neurons, suggesting that differentiated neurons may be a reasonable cell model to study $\alpha$-synuclein toxicity in PD.

\section{Acknowledgments}

We appreciate the support from Arizona Department of Health Services for the Arizona Department of Health Services for the Arizona Alzheimer's Consortium and the Michael J. Fox Foundation. We are grateful to the Banner/Sun Health Research Institute Brain Donation Program of Sun City, Arizona for the provision of human brain tissue. The Brain Donation Program is supported by the National Institute on Aging (P30 AG19610 Arizona Alzheimer's Disease Core Center), the Arizona Department of Health Services (contract 211002, Arizona Alzheimer's Research Center), the Arizona Biomedical Research Commission (contracts 4001, 0011, 05-901 and 1001 to the Arizona Parkinson's Disease Consortium) and the Prescott Family Initiative of the Michael J. Fox Foundation for Parkinson's Research. We would also give thanks to Debra Page Baluch in the Arizona State University (ASU) Keck's bioimaging laboratory for the access to microscopy facilities.

\section{Author Contributions}

Wei Xin performed most of the toxicity, cell staining, and wrote part of the manuscript. Sharareh Emadi performed the cell staining and wrote part of the manuscript. Stephanie Williams assayed the human brain tissue samples. Qiang Liu provided the rat primary neuron culture. Philip Schulz produced and validated the $10 \mathrm{H}$ and D5 scFvs. Ping He performed the cytochemistry studies. All of the authors discussed the results and contributed to the writing of the manuscript. Michael R. Sierks is the principal investigator and supervised the work.

\section{Conflicts of Interest}

The authors declare no conflict of interest.

\section{Abbreviations}

$\begin{array}{ll}\text { PD } & \text { Parkinson's disease } \\ \text { scFv } & \text { single chain antibody fragment } \\ \text { AFM } & \text { atomic force microscope } \\ \text { A30P } & \text { human A30P } \alpha \text {-synuclein mutation } \\ \text { A53T } & \text { human A53T } \alpha \text {-synuclein mutation } \\ \text { E46K } & \text { human E46K } \alpha \text {-synuclein mutation } \\ \text { SH-SY5Y } & \text { human neuroblastoma cells } \\ \text { CHO } & \text { Chinese hamster ovary cells } \\ \text { HEK } & \text { human embryonic kidney cells } \\ \text { TH } & \text { tyrosine hydroxylase }\end{array}$




$\begin{array}{ll}\text { RA } & \text { retinoic acid } \\ \text { BDNF } & \text { brain derived neurotrophic factor } \\ \text { ChAT } & \text { choline acetyltransferase } \\ \text { WTsynEGFP } & \alpha \text {-synuclein/EGFP fusion protein }\end{array}$

\section{References}

1. Recchiaa, A.; Rotaa, D.; Debettoa, P.; Peronib, D.; Guidolinc, D.; Negrob, A.; Skaperd, S.D.; Giustia, P. Generation of a alpha-synuclein-based rat model of Parkinson's disease. Neurobiol. Dis. 2008, 30, 8-18.

2. Polymeropoulos, M.H.; Lavedan, C.; Leroy, E.; Ide, S.E.; Dehejia, A.; Dutra, A.; Pike, B.; Root, H.; Rubenstein, J.; Boyer, R.; et al. Mutation in the alpha-synuclein gene identified in families with Parkinson's disease. Science 1997, 276, 2045-2047.

3. Gomez-Tortosa, E.; Newell, K.; Irizarry, M.C.; Albert, M.; Growdon, J.H.; Hyman, B.T. Clinical and quantitative pathologic correlates of dementia with Lewy bodies. Neurology 1999, 53, 1284-1291.

4. Schapira, A.H. Pathogenesis of Parkinson's disease. Baillieres Clin. Neurol. 1997, 6, 15-36.

5. Braak, H.; Del Tredici, K.; Rüb, U.; de Vos, R.A.; Jansen Steur, E.N.; Braak, E. Staging of brain pathology related to sporadic Parkinson's disease. Neurobiol. Aging 2003, 24, 197-211.

6. Halliday, G.M.; McCann, H. The progression of pathology in Parkinson's disease. Ann. NY Acad. Sci. 2010, 1184, 188-195.

7. Baba; M.; Nakajo, S.; Tu, P.H.; Tomita, T.; Nakaya, K.; Lee, V.M.; Trojanowski, J.Q.; Iwatsubo, T. Aggregation of alpha-synuclein in Lewy bodies of sporadic Parkinson's disease and dementia with Lewy bodies. Am. J. Pathol. 1998, 152, 879-884.

8. Conway, K.A.; Harper, J.D.; Lansbury, P.T. Accelerated in vitro fibril formation by a mutant alpha-synuclein linked to early-onset Parkinson disease. Nat. Med. 1998, 4, 1318-1320.

9. Mezey, E.; Eisenhofer, G.; Hansson, S.; Harta, G.; Hoffman, B.J.; Gallatz, K.; Palkovits, M.; Hunyady, B. Non-neuronal dopamine in the gastrointestinal system. Clin. Exp. Pharmacol. Physiol. Suppl. 1999, 26, S14-S22.

10. Spillantini, M.G.; Crowther, R.A.; Jakes, R.; Hasegawa, M.; Goedert, M. alpha-Synuclein in filamentous inclusions of Lewy bodies from Parkinson's disease and dementia with lewy bodies. Proc. Natl. Acad. Sci. USA 1998, 95, 6469-6473.

11. Spillantini, M.G.; Schmidt, M.L.; Lee, V.M.; Trojanowski, J.Q.; Jakes, R.; Goedert, M. alpha-synuclein in Lewy bodies. Nature 1997, 388, 839-840.

12. Singleton, A.B.; Farrer, M.; Johnson, J.; Singleton, A.; Hague, S.; Kachergus, J.; Hulihan, M.; Peuralinna, T.; Dutra, A.; Nussbaum, R.; et al. alpha-Synuclein locus triplication causes Parkinson's disease. Science 2003, doi:10.1126/science.1090278.

13. Zarranz, J.J.; Alegre, J.; Gómez-Esteban, J.C.; Lezcano, E.; Ros, R.; Ampuero, I.; Vidal, L.; Hoenicka, J.; Rodriguez, O.; Atarés, B.; et al. The new mutation, E46K, of alpha-synuclein causes Parkinson and Lewy body dementia. Ann. Neurol. 2004, 55, 164-173. 
14. Iwai; A; Masliah, E.; Yoshimoto, M.; Ge, N.; Flanagan, L.; de Silva, H.A.; Kittel, A.; Saitoh, T. The precursor protein of non-A beta component of Alzheimer's disease amyloid is a presynaptic protein of the central nervous system. Neuron 1995, 14, 467-475.

15. Cappai, R.; Leck, S.L.; Tew, D.J.; Williamson, N.A.; Smith, D.P.; Galatis, D.; Sharples, R.A.; Curtain, C.C.; Ali, F.E.; Cherny, R.A.; et al. Dopamine promotes alpha-synuclein aggregation into SDS-resistant soluble oligomers via a distinct folding pathway. FASEB J. 2005, 19, 1377-1379.

16. Cohlberg, J.A.; Li, J.; Uversky, V.N.; Fink, A.L. Heparin and other glycosaminoglycans stimulate the formation of amyloid fibrils from alpha-synuclein in vitro. Biochemistry 2002, 41, 1502-1511.

17. Hoyer, W.; Antony, T.; Cherny, D.; Heim, G.; Jovin, T.M.; Subramaniam, V. Dependence of alpha-synuclein aggregate morphology on solution conditions. J. Mol. Biol. 2002, 322, 383-393.

18. Lowe, R.; Pountney, D.L.; Jensen, P.H.; Gai, W.P.; Voelcker, N.H. Calcium(II) selectively induces alpha-synuclein annular oligomers via interaction with the $\mathrm{C}$-terminal domain. Protein Sci. 2004, 13, 3245-3252.

19. Uversky, V.N.; Li, J.; Fink, A.L. Metal-triggered structural transformations, aggregation, and fibrillation of human alpha-synuclein. A possible molecular NK between Parkinson's disease and heavy metal exposure. J. Biol. Chem. 2001, 276, 44284-44296.

20. Emadi, S.; Barkhordarian, H.; Wang, M.S.; Schulz, P.; Sierks, M.R. Isolation of a human single chain antibody fragment against oligomeric alpha-synuclein that inhibits aggregation and prevents alpha-synuclein-induced toxicity. J. Mol. Biol. 2007, 368, 1132-1144.

21. Emadi, S.; Kasturirangan, S.; Wang, M.S.; Schulz, P.; Sierks, M.R. Detecting morphologically distinct oligomeric forms of alpha-synuclein. J. Biol. Chem. 2009, 284, 11048-11058.

22. Kayed, R.; Head, E.; Thompson, J.L.; McIntire, T.M.; Milton, S.C.; Cotman, C.W.; Glabe, C.G. Common structure of soluble amyloid oligomers implies common mechanism of pathogenesis. Science 2003, 300, 486-489.

23. Volles, M.J.; Lansbury, P.T., Jr. Zeroing in on the pathogenic form of alpha-synuclein and its mechanism of neurotoxicity in Parkinson's disease. Biochemistry 2003, 42, 7871-7878.

24. Volles, M.J.; Lee, S.J.; Rochet, J.C.; Shtilerman, M.D.; Ding, T.T.; Kessler, J.C.; Lansbury, P.T. Vesicle permeabilization by protofibrillar alpha-synuclein: Implications for the pathogenesis and treatment of Parkinson's disease. Biochemistry 2001, 40, 7812-7819.

25. Periquet, M.; Fulga, T.; Myllykangas, L.; Schlossmacher, M.G.; Feany, M.B. Aggregated alpha-synuclein mediates dopaminergic neurotoxicity in vivo. J. Neurosci. 2007, 27, 3338-3346.

26. Danzer, K.M.; Haasen, D.; Karow, A.R.; Moussaud, S.; Habeck, M.; Giese, A.; Kretzschmar, H.; Hengerer, B.; Kostka, M. Different species of alpha-synuclein oligomers induce calcium influx and seeding. J. Neurosci. 2007, 27, 9220-9232.

27. Borghi, R.; Marchese, R.; Negro, A.; Marinelli, L.; Forloni, G.; Zaccheo, D.; Abbruzzese, G.; Tabaton, M. Full length alpha-synuclein is present in cerebrospinal fluid from Parkinson's disease and normal subjects. Neurosci. Lett. 2000, 287, 65-67.

28. El-Agnaf, O.M.; Salem, S.A.; Paleologou, K.E.; Curran, M.D.; Gibson, M.J.; Schlossmacher, M.G.; Allsop, D. Detection of oligomeric forms of alpha-synuclein protein in human plasma as a potential biomarker for Parkinson's disease. FASEB J. 2006, 20, 419-425. 
29. Lee, P.H.; Lee, G.; Park, H.J.; Bang, O.Y.; Joo, I.S.; Huh, K. The plasma alpha-synuclein levels in patients with Parkinson's disease and multiple system atrophy. J. Neural. Transm. 2006, 113, 1435-1439.

30. Sierks, M.R.; Chatterjee, G.; McGraw, C.; Kasturirangan, S.; Schulz, P.; Prasad, S. CSF levels of oligomeric alpha-synuclein and beta-amyloid as biomarkers for neurodegenerative disease. Integr. Biol. 2011, 3, 1188-1196.

31. Tokuda, T.; Qureshi, M.M.; Ardah, M.T.; Varghese, S.; Shehab, S.A.S.; Kasai, T.; Ishigami, N.; Tamaoka, A.; Nakagawa, M.; El-Agnaf, O.M.A. Detection of elevated levels of alpha-synuclein oligomers in CSF from patients with Parkinson disease. Neurology 2010, 75, 1766-1772.

32. Barkhordarian, H.; Emadi, S.; Schulz, P.; Sierks, M.R. Isolating recombinant antibodies against specific protein morphologies using atomic force microscopy and phage display technologies. Protein Eng. Des. Sel. 2006, 19, 497-502.

33. Encinas, M.; Iglesias, M.; Liu, Y.; Wang, H.; Muhaisen, A.; Cena, V.; Gallego, C.; Comella, J.X. Sequential treatment of SH-SY5Y cells with retinoic acid and brain-derived neurotrophic factor gives rise to fully differentiated, neurotrophic factor-dependent, human neuron-like cells. J. Neurochem. 2000, 75, 991-1003.

34. Pahlman, S.; Hoehner, J.C.; Nånberg, E.; Hedborg, F.; Fagerström, S.; Gestblom, C.; Johansson, I.; Larsson, U.; Lavenius, E.; Örtoft, E.; et al. Differentiation and survival influences of growth factors in human neuroblastoma. Eur. J. Cancer 1995, 31, 453-458.

35. Presgraves, S.P.; Ahmed, T.; Borwege, S.; Joyce, J.N. Terminally differentiated SH-SY5Y cells provide a model system for studying neuroprotective effects of dopamine agonists. Neurotox. Res. 2004, 5, 579-598.

36. Xie, H.R.; Hu, L.S.; Li, G.Y. SH-SY5Y human neuroblastoma cell line: In vitro cell model of dopaminergic neurons in Parkinson's disease. Chin. Med. J. 2010, 123, 1086-1092.

37. Wakabayashi, K.; Yoshimoto, M.; Tsuji, S.; Takahashi, H. Alpha-synuclein immunoreactivity in glial cytoplasmic inclusions in multiple system atrophy. Neurosci. Lett. 1998, 249, 180-182.

38. Bartels, T.; Choi, J.G.; Selkoe, D.J. alpha-Synuclein occurs physiologically as a helically folded tetramer that resists aggregation. Nature 2011, 477, 107-110.

39. Lashuel, H.A.; Hartley, D.; Petre, B.M.; Walz, T.; Lansbury, P.T. Neurodegenerative disease: Amyloid pores from pathogenic mutations. Nature 2002, doi:10.1038/418291a.

40. Ding, T.T.; Lee, S.J.; Rochet, J.C.; Lansbury, P.T. Annular alpha-synuclein protofibrils are produced when spherical protofibrils are incubated in solution or bound to brain-derived membranes. Biochemistry 2002, 41, 10209-10217.

41. Jo, E.; McLaurin, J.; Yip, C.M.; George-Hyslop, P.S.; Fraser, P.E. alpha-Synuclein membrane interactions and lipid specificity. J. Biol. Chem. 2000, 275, 34328-34334.

42. Lee, H.J.; Choi, C.; Lee, S.J. Membrane-bound alpha-synuclein has a high aggregation propensity and the ability to seed the aggregation of the cytosolic form. J. Biol. Chem. 2002, 277, 671-678.

43. Alim, M.A.; Hossain, M.S.; Arima, K.; Takeda, K.; Izumiyama, Y.; Nakamura, M.; Kaji, H.; Shinoda, T.; Hisanaga, S.; Ueda, K. Tubulin seeds alpha-synuclein fibril formation. J. Biol. Chem. 2002, 277, 2112-2117.

44. Giasson, B.I.; Forman, M.S.; Higuchi, M.; Golbe, L.I.; Graves, C.L.; Kotzbauer, P.T.; Trojanowski, J.Q.; Lee, V.M. Initiation and synergistic fibrillization of tau and alpha-synuclein. Science 2003, 300, 636-640. 
45. Lindersson, E.; Lundvig, D.; Petersen, C.; Madsen, P.; Nyengaard, J.R.; Højrup, P.; Moos, T.; Otzen, D.; Gai, W.P.; Blumbergs, P.C.; et al. p25a Stimulates alpha-synuclein aggregation and is co-localized with aggregated alpha-synuclein in alpha-synucleinopathies. J. Biol. Chem. 2005, 280, 5703-5715.

46. Conway, K.A.; Rochet, J.C.; Bieganski, R.M.; Lansbury, P.T., Jr. Kinetic stabilization of the alpha-synuclein protofibril by a dopamine-alpha-synuclein adduct. Science 2001, 294, 1346-1349.

47. Paleologou, K.E.; Kragh, C.L.; Mann, D.M.; Salem, S.A.; Al-Shami, R.; Allsop, D.; Hassan, A.H.; Jensen, P.H.; El-Agnaf, O.M. Detection of elevated levels of soluble alpha-synuclein oligomers in post-mortem brain extracts from patients with dementia with Lewy bodies. Brain 2009, 132, $1093-1101$.

48. Lorenzen, N.; Nielsen, S.B.; Yoshimura, Y.; Vad, B.S.; Andersen, C.B.; Betzer, C.; Kaspersen, J.D.; Christiansen, G.; Pedersen, J.S.; Jensen, P.H.; et al. How epigallocatechin gallate can inhibit alpha-synuclein oligomer toxicity in vitro. J. Biol. Chem. 2014, 289, 21299-21310.

49. Williams, S.; Schulz, P.; Sierks, M.R. A Sensitive phage-based capture ELISA for sub-femtomolar detection of protein variants directly from biological samples. Biotechnol. Prog. 2015, 31, 289-298.

50. Jamsa, A.; Hasslund, K.; Cowburn, R.F.; Bäckström, A.; Vasänge, M. The retinoic acid and brain-derived neurotrophic factor differentiated SH-SY5Y cell line as a model for Alzheimer's disease-like tau phosphorylation. Biochem. Biophys. Res. Commun. 2004, 319, 993-1000.

51. Lopes, F.M.; Schröder, R.; da Frota, M.L., Jr.; Zanotto-Filho, A.; Müller, C.B.; Pires, A.S.; Meurer, R.T.; Colpo, G.D.; Gelain, D.P.; Kapczinski, F.; et al. Comparison between proliferative and neuron-like SH-SY5Y cells as an in vitro model for Parkinson disease studies. Brain Res. 2010, 1337, 85-94.

52. Prince, J.A.; Oreland, L. Staurosporine differentiated human SH-SY5Y neuroblastoma cultures exhibit transient apoptosis and trophic factor independence. Brain Res. Bull. 1997, 43, 515-523.

53. Rubio, A.; Avila, J.; Perez, M. Effect of acetylcholine on tau phosphorylation in human neuroblastoma cells. J. Mol. Neurosci. 2006, 30, 185-188.

54. Cook, C.; Stetler, C.; Petrucelli, L. Disruption of protein quality control in Parkinson's disease. Cold Spring Harb. Perspect. Med. 2012, doi:10.1101/cshperspect.a009423.

55. Grey, M.; Dunning, C.J.; Gaspar, R.; Grey, C.; Brundin, P.; Sparr, E.; Linse, S. Acceleration of alpha-synuclein aggregation by exosomes. J. Biol. Chem. 2014, 290, 2969-2982.

56. Poehler, A.M.; Xiang, W.; Spitzer, P.; May, V.E.; Meixner, H.; Rockenstein, E.; Chutna, O.; Outeiro, T.F.; Winkler, J.; Masliah, E.; et al. Autophagy modulates SNCA/alpha-synuclein release, thereby generating a hostile microenvironment. Autophagy 2014, 10, 2171-2192.

57. Walsh, D.M.; Fadeeva, J.V.; LaVoie, M.J.; Paliga, K.; Eggert, S.; Kimberly, W.T.; Wasco, W.; Selkoe, D.J. gamma-Secretase cleavage and binding to FE65 regulate the nuclear translocation of the intracellular C-terminal domain (ICD) of the APP family of proteins. Biochemistry 2003, 42, 6664-6673.

(C) 2015 by the authors; licensee MDPI, Basel, Switzerland. This article is an open access article distributed under the terms and conditions of the Creative Commons Attribution license (http://creativecommons.org/licenses/by/4.0/). 